\title{
The effects of grafted mesenchymal stem cells labeled with iron oxide or cobalt-zinc-iron nanoparticles on the biological macromolecules of rat brain tissue extracts
}

\author{
This article was published in the following Dove Press journal: \\ International Journal of Nanomedicine \\ 20 June 2017 \\ Number of times this article has been viewed
}

\section{Bozena Novotna' \\ Vit Herynek ${ }^{2}$ \\ Pavel Rossner Jr' \\ Karolina Turnovcova ${ }^{3}$ \\ Pavla Jendelova ${ }^{3}$ \\ 'Department of Genetic Toxicology and Nanotoxicology, Institute of \\ Experimental Medicine AS CR, v.v.i., ${ }^{2}$ Magnetic Resonance Unit, \\ Radiodiagnostic and Interventional Radiology Department, Institute for Clinical and Experimental Medicine, ${ }^{3}$ Department of Tissue Culture and Stem Cells, Institute of Experimental Medicine AS CR, v.v.i., Prague, Czech Republic}

Introduction: Rat mesenchymal stem cells (rMSCs) labeled with 1) poly-L-lysine-coated superparamagnetic iron oxide nanoparticles or 2) silica-coated cobalt-zinc-iron nanoparticles were implanted into the left brain hemisphere of rats, to assess their effects on the levels of oxidative damage to biological macromolecules in brain tissue.

Methods: Controls were implanted with unlabeled rMSCs. Animals were sacrificed 24 hours or 4 weeks after the treatment, and the implantation site along with the surrounding tissue was isolated from the brain. At the same intervals, parallel groups of animals were scanned in vivo by magnetic resonance imaging (MRI). The comet assay with enzymes of excision DNA repair (endonuclease III and formamidopyrimidine-DNA glycosylase) was used to analyze breaks and oxidative damage to DNA in the brain tissue. Oxidative damage to proteins and lipids was determined by measuring the levels of carbonyl groups and 15- $\mathrm{F}_{2 \mathrm{t}}$-isoprostane (enzyme-linked immunosorbent assay). MRI displayed implants of labeled cells as extensive hypointense areas in the brain tissue. In histological sections, the expression of glial fibrillary acidic protein and CD68 was analyzed to detect astrogliosis and inflammatory response.

Results: Both contrast labels caused a similar response in the $\mathrm{T}_{2}$-weighted magnetic resonance (MR) image and the signal was clearly visible within 4 weeks after implantation of rMSCs. No increase of oxidative damage to DNA, lipids, or proteins over the control values was detected in any sample of brain tissue from the treated animals. Also, immunohistochemistry did not indicate any serious tissue impairment around the graft.

Conclusion: Both tested types of nanoparticles appear to be prospective and safe labels for tracking the transplanted cells by MR.

Keywords: MRI, comet assay, genotoxicity, lipid peroxidation, protein oxidative damage, cell transplantation

\section{Introduction}

Transplantation of stem cells represents a perspective approach for the treatment of multiple human diseases and disorders. To assess the efficacy of stem cell therapy, magnetic resonance imaging (MRI) combined with a contrast label appears to be an effective noninvasive technique for the tracking of transplanted stem cells in living organisms. The application of MRI in vivo requires the use of a safe contrast agent, that is, the achievement of a sufficient level of cell labeling for MRI and, simultaneously, biocompatibility of the label with stem cells and the host tissue without any side effects on their biological properties and functions. ${ }^{1}$ Due to their physicochemical properties, superparamagnetic
Correspondence: Bozena Novotna Department of Genetic Toxicology and Nanotoxicology, Institute of Experimental Medicine AS CR, v.v.i., Videnska 1083 14220 Prague 4, Czech Republic

Tel +420241062209

Fax +42024I 062785

Email novotna@biomed.cas.cz (c)
hereby accept the Terms. Non-commercial uses of the work are permitted without any further permission from Dove Medical Press Limited, provided the work is properly attributed. For permission hereby accept the Terms. Non-commercial uses of the work are permitted without any further permission from Dove Medice
for commercial use of this work, please see paragraphs 4.2 and 5 of our Terms (https://www.dovepress.com/terms.php). 
iron oxide nanoparticles (SPIONs) are frequently used as suitable cellular MRI probes. However, currently available information on their potential adverse health effects is still not satisfactory, and controversial data have been reported. ${ }^{2,3}$ Generally, these data originate from in vitro experiments where the conditions differ considerably from an in vivo situation. ${ }^{4}$ In addition, the transformed neoplastic cell lines that have a different pathophysiology from normal cells are usually employed for in vitro toxicity testing of nanoparticles, which may also contribute to questionable results. ${ }^{5}$ On the other hand, in vivo studies are less frequent and they are aimed almost exclusively at the effects of nanoparticles per se. ${ }^{6,7}$ Until now, only one paper ${ }^{7}$ has reported findings of the same SPIONs both in cells (mouse embryonic fibroblasts NIH3T3) and in animals (Wistar rats).

In our previous experiment, we used human bone marrow mesenchymal stem cells (hBMSCs), that is, cells with therapeutic potential, for analysis of the biological effects of several SPIONs varying in their surface coating. ${ }^{8}$ The results revealed a strong capability of SPIONs to induce oxidative injury to lipids, proteins, and DNA in labeled cells. Particularly, the levels of lipid peroxidation were high (even in the absence of cytotoxicity) and increased further with time, regardless of the type of nanoparticle coating which could significantly influence the therapeutic functions of cells in the host. Among the tested SPIONs, those coated with poly-Llysine (PLL) induced relatively low levels of oxidative damage in comparison with other types and seemed, therefore, to be the most suitable for application in vivo.

In the subsequent study, we analyzed the effects of silicacoated cobalt-zinc-ferrite nanoparticles (CZF-NPs) as an alternative to SPIONs. ${ }^{9}$ In this case, no oxidative damage to biological macromolecules was detected in rat mesenchymal stem cells (rMSCs) exposed to a nontoxic dose of CZF-NPs. Nevertheless, the labeled cells still exhibited an adequate relaxation rate for MRI.

A question arose as to whether the implantation of rMSCs labeled with these two types of nanoparticles may represent a higher risk of oxidative stress for the host than the unlabeled implant. Therefore, rMSCs labeled with PLL-coated SPIONs or silica-coated CZF-NPs were implanted into the brains of rats with the aim to assess their effects in vivo. All physicochemical characteristics of nanoparticles along with their intracellular localization in vitro have already been detailed. ${ }^{89}$ In this study, we thus focused exclusively on the level of oxidative damage to biological macromolecules in the brain tissue at a probe concentration suitable for MRI tracking.

\section{Materials and methods Mesenchymal stem cell preparation and labeling}

Five 3-week-old Lewis male rats (Envigo, formerly Harlan Laboratories BV, NM Horst, the Netherlands) were anesthetized with 2\% isoflurane (Forane; Aesica Queenborough Ltd, Queenborough, Kent, UK), and sacrificed with an intracardial injection of T61 (Intervet International, Boxmeer, the Netherlands). Long bones were removed and the bone marrow was flushed and suspended in freshly prepared medium preheated at $37^{\circ} \mathrm{C}$ and consisting of high glucose Dulbecco's Modified Eagle's Medium (DMEM; SigmaAldrich, St Louis, MO, USA), 10\% fetal bovine serum (FBS; PAA Laboratories GmbH, Pasching, Austria), and $2 \mathrm{~mL} / \mathrm{mL}$ Primocin (Invivogen, San Diego, CA, USA). The bone marrow cell suspension was plated onto $10 \mathrm{~cm}$ polystyrene Petri dishes (Techno Plastic Products, Trasadingen, Switzerland) in an amount equivalent to the bone marrow of one bone per dish. After 48 hours, non-adherent cells were washed out and adherent mesenchymal stem cells were cultivated as described previously. ${ }^{9}$ During the third passage, the suspension of nanoparticles was added directly to the cell culture at a final concentration of $15 \mu \mathrm{g}$ of metallic ions (represented by iron in SPIONs and iron, cobalt, and zinc in CZF-NPs) per mL of cell culture media. Preparation of both types of NPs as well as a thorough description of their physicochemical properties have already been reported..$^{9,10}$

The cells with NPs were incubated for 48 hours, then washed with preheated phosphate-buffered saline (PBS; IKEM, Prague, Czech Republic), harvested using 0.05\% trypsin/EDTA (Sigma-Aldrich), and the cell suspension was prepared at a concentration of 100,000 cells per $2 \mu \mathrm{L}$ of complete media.

rMSCs were characterized previously according to minimal criteria. ${ }^{11}$ Cells from the bone marrow were isolated on the basis of their adherence to plastic, while non-adherent cells were removed. Adherent cells during subsequent passages were differentiated into adipoblasts, osteoblasts, and chondroblasts. ${ }^{12,13}$ Flow cytometry revealed strong positivity for CD90 and weak positivity for CD105, but cells were negative for CD3, CD34, CD45RA, and CD73 (Turnovcova, unpublished data, 2015). In culture, the cells were positive for CD90 and fibronectin and negative for CD11b and CD45. ${ }^{14}$

\section{Treatment of animals}

Twelve Lewis male rats (275-300 g) (Envigo) were divided into three groups consisting of four animals. One group was administered with SPION-labeled rMSCs, the second with 
CZF-labeled rMSCs, and the third group served as a negative control, that is, the animals received unlabeled rMSCs. Rats were anesthetized with $2 \%$ isoflurane, and $2 \mu \mathrm{L}$ of cell suspension was implanted into the left striatum (coordinates from bregma A-P $\pm 0.5 \mathrm{~mm}, 3 \mathrm{~mm}$ lateral, and D-V $5 \mathrm{~mm}$ from dura). Two rats from each group were sacrificed the next day and another six rats survived up to 1 month after implantation with periodical MRI scanning.

All experiments were performed in accordance with the European Communities Council Directive of September 22, $2010(2010 / 63 / \mathrm{EU})$ regarding the use of animals in research, and were approved by the Ethics Committee of the Institute of Experimental Medicine, Academy of Sciences of the Czech Republic.

\section{MRI}

All in vivo MRI experiments were performed on a Bruker BioSpec 4.7 T imager (Bruker BioSpin, Ettlingen, Germany). The animals were anesthetized by passive inhalation of isoflurane (Chiesi Pharmaceuticals, Vienna, Austria) in air ( $5 \%$ for induction, $1 \%-2 \%$ for maintenance). The animals were placed on a heated holder in a prone position. A surface transmit-receive coil covering the whole brain was placed over their head. Breathing was monitored during the whole measurement. Animals were scanned within 24 hours after cell implantation, and 1 and 4 weeks after cell implantation.

Transversal and sagittal slices were measured using a standard $\mathrm{T}_{2}$-weighted turbo spin echo sequence (effective echo time $\mathrm{TE}=36 \mathrm{~ms}$, repetition time $\mathrm{TR}=3,000 \mathrm{~ms}$, field of view $=35 \times 35 \mathrm{~mm}^{2}$, matrix $256 \times 256$, slice thickness $0.5 \mathrm{~mm}$ ). The protocol was supplemented by transversal slices measured by a strongly $\mathrm{T}_{2}$-weighted turbo spin echo $(\mathrm{TE}=60 \mathrm{~ms}$, $\mathrm{TR}=3,000 \mathrm{~ms}$ ) and $\mathrm{T}_{2}{ }^{*}$-weighted gradient echo sequences $\left(\mathrm{TE}=6 \mathrm{~ms}, \mathrm{TR}=400 \mathrm{~ms}\right.$, flip angle $30^{\circ}$ ).

\section{Preparation of cell suspensions from the brains of treated animals}

Rats were anesthetized with $2 \%$ isoflurane (Forane; Aesica Queenborough Ltd), euthanized with an intracardial injection of T61 (Intervet International), and the brains were quickly removed. The implantation site and surrounding tissue $(5 \times 5 \times 5 \mathrm{~mm}$ fragment) was isolated, quickly dissociated with scissors in Hank's balanced salt solution (Sigma-Aldrich), and after a quick spin, tissue bits were enzymatically digested in $2.5 \mathrm{mg}$ trypsin (Sigma-Aldrich) and $5 \mathrm{mg}$ collagenase IV (Thermo Fisher Scientific, Waltham, MA, USA) in $5 \mathrm{~mL}$ DMEM for 20 minutes at $37^{\circ} \mathrm{C}$. Then, $10 \mathrm{~mL}$ of DMEM and 10\% FBS (Thermo Fisher Scientific) were added, tissue suspension was triturated thoroughly with a Pasteur glass pipette, and cell suspension was filtered through a $40 \mu \mathrm{m} \mathrm{BD}$ Falcon Cell Strainer (BD Biosciences, San Jose, CA, USA). After centrifugation ( 5 minutes, 4,000 rpm), the supernatant was removed and the pellet was resuspended in freshly prepared DMEM. Cell suspension was then labeled with cell-permeant nucleic acid dye acridine orange ( $\mathrm{AO}, 1 \mu \mathrm{g} / \mathrm{mL}$ stock, 1:100 labeling solution), and nucleated cell (AO positive) concentration was assessed using an Apogee A50 Micro flow cytometer (Apogee Flow Systems, Hertfordshire, UK). Cell suspension was adjusted to 800,000 cells per $\mathrm{mL}$. In parallel, a corresponding piece of tissue from the left hemisphere of each animal was isolated and processed in the same way to determine the possible difference between the treated and untreated hemispheres.

\section{DNA damage}

DNA damage in the brain cells of treated animals was analyzed using an alkaline version of the comet assay. ${ }^{15,16}$ In order to detect both DNA strand breaks and oxidized bases, the assay was combined with specific bacterial repair enzymes Fpg and ENDO III. ${ }^{17}$ Two slides per sample from brain cell suspensions were prepared and further processed, as described previously. ${ }^{8,18}$

Comet images were captured with a CCD-1300B camera (VDS Vosskuhler, Germany) attached to a BX51 fluorescence microscope (Olympus, Japan). The extent of DNA migration was quantified using Lucia Comet Assay 7.00 software (Laboratory Imaging, Prague, Czech Republic) and the results are expressed as a percentage of DNA in the tail (tail DNA \%). The total DNA damage was measured in 100 randomly selected cells per slide, and medians were calculated from every group of 100 cells. Four medians obtained per sample were then used for statistical analysis. The differences between the groups were analyzed using unpaired two-tailed $t$-test.

\section{Oxidative damage to lipids and proteins}

Following the assessment of DNA damage, the remaining cells were centrifuged at $400 \times g$ and the cell pellets were stored at $-80^{\circ} \mathrm{C}$. To prepare lysates, the cell pellets were thawed, mixed with $100 \mathrm{~mL}$ of CelLytic reagent (Sigma-Aldrich), and incubated for 15 minutes at room temperature on a shaker, mixing vigorously. The samples were then centrifuged for 15 minutes at $16,600 \times g$ at $4^{\circ} \mathrm{C}$. The supernatants were transferred to new tubes, and either stored at $-80^{\circ} \mathrm{C}$ or used directly for the analysis of total protein concentration using a Bicinchoninic Acid Kit (Sigma-Aldrich). 
The concentration of $15-\mathrm{F}_{2 \mathrm{t}}$-IsoP and protein carbonyls in the brain cells was analyzed as previously described. ${ }^{8,9}$ $15-\mathrm{F}_{2 \mathrm{t}}$-IsoP was assessed in samples containing $50 \mu \mathrm{g}$ of total proteins, using immunoassay kits from Cayman Chemical (Ann Arbor, MI, USA). Protein oxidation was analyzed in derivatized samples containing $200 \mathrm{ng}$ of total proteins, using a previously published protocol. ${ }^{19}$ Each sample was analyzed in triplicate. The differences between the groups were analyzed using $t$-test.

\section{Histology and immunohistochemistry}

Simultaneously with the MRI experiments, the same number of CZF-NPs or SPION-labeled cells was injected into the rat hemisphere. Unlabeled cells were injected into the contralateral hemisphere and served as a control. One month after grafting, anesthetized rats $(n=4)$ were perfused with $4 \%$ paraformaldehyde in 0.1 M PBS ( $\mathrm{pH} 7.4$ ). Fixed brains were dissected and immersed in PBS with 30\% sucrose. Frozen coronal sections $(40 \mu \mathrm{m})$ were cut through the areas of interest. Sections with implants were stained for iron to produce ferric ferrocyanide (Prussian blue) and by anti-glial fibrillary acidic protein (1:1,000; Sigma-Aldrich) or anti-CD68 antibody (1:100; Bio-Rad Laboratories, Hercules, CA, USA) to detect astrogliosis or inflammatory response. Staining was visualized using an avidin/biotin-based peroxidase system VECTASTAIN Elite ABC HRP Kit (1:400; Vector Laboratories, Burlingame, CA, USA). Sections were counterstained with nuclear red.

\section{Results and discussion MRI}

An edema in the left cortex was visible as a hyperintense area immediately after implantation of the unlabeled cells into the brain (Figure 1A). A small hypointense area just under the skull had its origin in heme iron from blood. Whereas the edema vanished within 1 week, the small hypointense area remained visible in the cortex until the end of the experiment. Bleeding was also responsible for the fine hypointense line along the needle trace. The implant consisting of unlabeled cells is invisible, as the cells provided a similar magnetic resonance (MR) signal to the normal brain tissue.

Implanted cells labeled by SPIONs (Figure 1B) or CZF-NPs (Figure 1C) manifested themselves as extensive
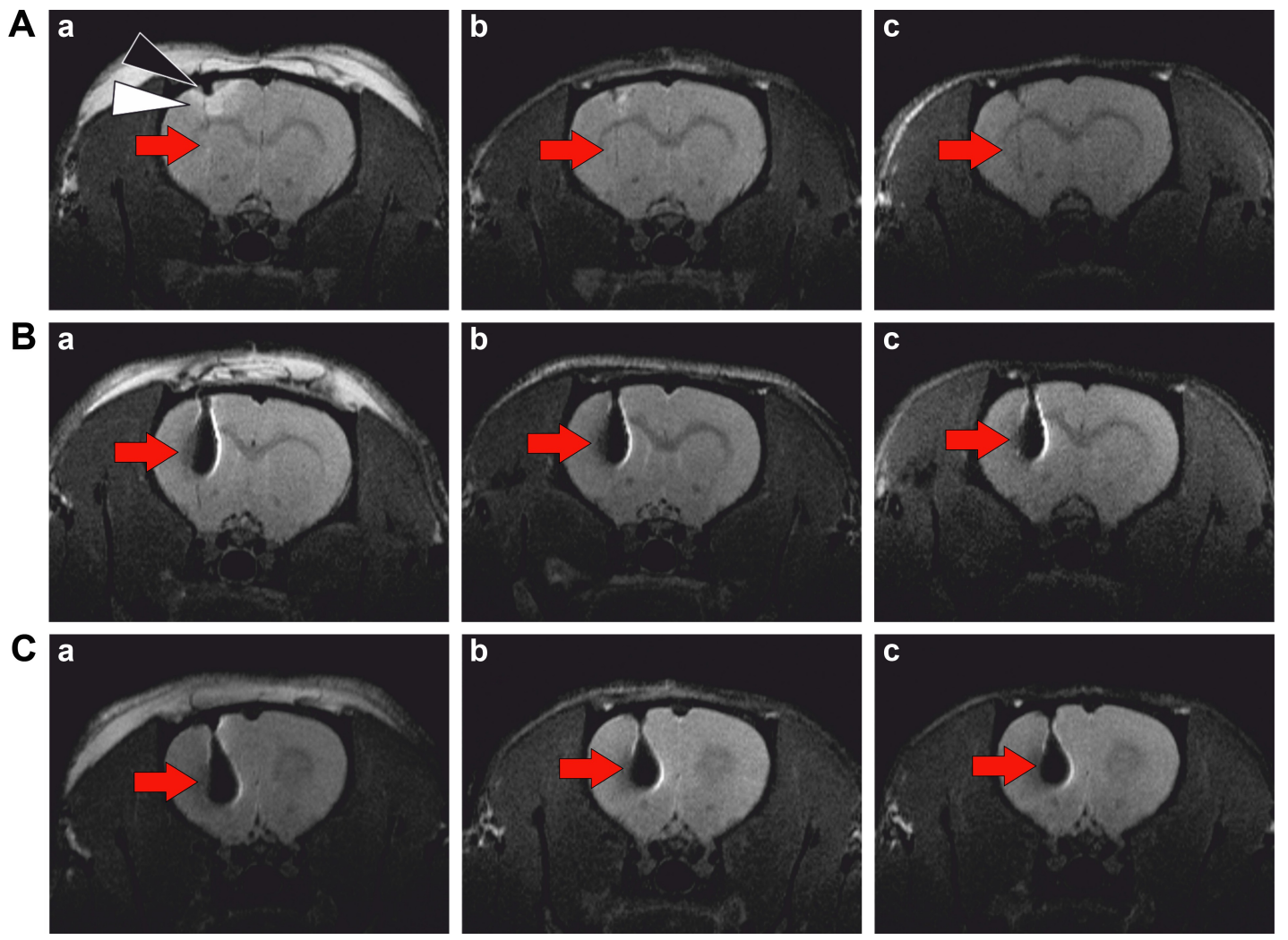

Figure I MR imaging of a rat brain.

Notes: $T_{2}$-weighted images after implantation of $(\mathbf{A})$ unlabeled cells, $(\mathbf{B})$ cells labeled by SPIONs, $(\mathbf{C})$ cells labeled by CZF-NPs. Red arrows indicate the location of the cell implant. MR images were obtained (a) within 24 hours after implantation, (b) I week, and (c) 4 weeks after implantation. An edema (white triangle) in the left cortex was visible as a hyperintense area immediately after implantation of the unlabeled cells into the brain (A), which vanished within I week, whereas a small hypointense area just under the skull, originating from heme iron from blood (black triangle), remained visible until the end of the experiment.

Abbreviations: CZF-NPs, cobalt-zinc-ferrite nanoparticles; SPIONs, superparamagnetic iron oxide nanoparticles; MR, magnetic resonance. 
hypointense areas. Both contrast labels caused a similar response in the $\mathrm{T}_{2}$-weighted MR image. The lesion did not substantially change within 4 weeks after implantation.

Stronger $\mathrm{T}_{2}$-weighting (Figure $2 \mathrm{~A}$ and $\mathrm{B}$ ) provides a similar contrast change in the MR image as standard $\mathrm{T}_{2}$-weighting and has no substantial impact on cell implant detectability. However, the $\mathrm{T}_{2}{ }^{*}$-weighted image, which reveals less anatomical details and usually has a lower signal-to-noise ratio, is more susceptible to local field inhomogeneities and, therefore, is suitable for magnetic particle detection. Ferromagnetic CZF-NPs created stronger inhomogeneities in a bigger area than superparamagnetic SPIONs; therefore the impacted area represented by the hypointense signal in the $\mathrm{T}_{2}{ }^{*}$-weighted image was, in the case of CZF-NPs, bigger (Figure 2C and D).

\section{Immunohistochemistry and oxidative damage to biological macromolecules}

Grafted cells survived in the tissue for the whole period and nanoparticles were detected by Prussian blue staining. Only mild astrogliosis was detected around the transplant
(Figure 3A-C) and a small number of CD68 positive macrophages surrounded the graft (Figure 3D-F). To document the low extent of astrogliosis and inflammation, we performed staining for astrocytes and CD68 in healthy tissue without transplant (Figure $3 \mathrm{G}$ and $\mathrm{H}$ ). Staining visualized using an avidin/biotin-based peroxidase system but omitting the primary antibody served as a negative control (Figure 3I).

None of the brain tissue samples with the implant of labeled rMSCs exhibited an increase of oxidative damage to DNA, proteins, or lipids over the control values assessed in the samples treated with unlabeled rMSCs, either in the short ( 24 hours) or long ( 4 weeks) interval after the treatment (Table 1; Figure 4). The same result was observed when the tissues from treated hemispheres were compared with their untreated counterparts (data not shown). In our previous in vitro experiments, all tested SPIONs induced significant oxidative damage in cells, although those coated with PLL showed the most promising results. ${ }^{8}$ As the present results were obtained from a mixture of rMSCs and brain tissue, we cannot quite exclude the possibility that the possible damage to the implanted cells could be "diluted" by a
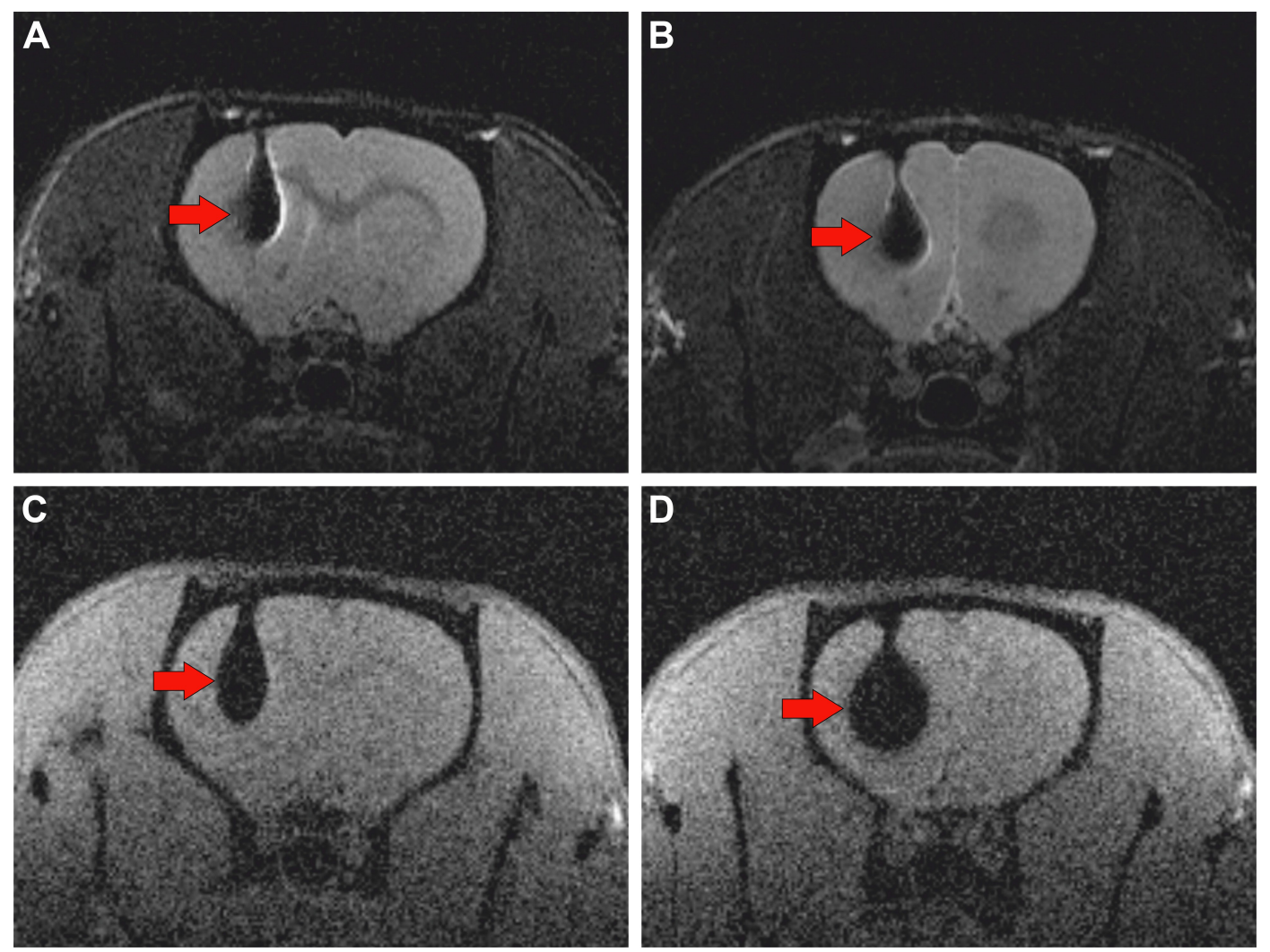

Figure 2 Comparison of two MR sequences.

Notes: MR images of implanted cells labeled by SPIONs $(\mathbf{A}, \mathbf{C})$ and by CZF-NPs (B, D) were obtained using a strongly $\mathrm{T}_{2}$-weighted turbo spin echo sequence (A, B), and using a $\mathrm{T}_{2}{ }^{*}$-weighted gradient echo sequence $(\mathbf{C}, \mathbf{D})$. Although the gradient echo sequence provided less anatomical details, due to its susceptibility to local field inhomogeneities, it was more sensitive to the presence of magnetic nanoparticles. Ferromagnetic CZF-NPs created stronger inhomogeneities; thus, the impacted area represented by the hypointense signal was bigger (D) than in the case of superparamagnetic SPIONs (C). Red arrows indicate the location of the cell implant.

Abbreviations: CZF-NPs, cobalt-zinc-ferrite nanoparticles; SPIONs, superparamagnetic iron oxide nanoparticles; MR, magnetic resonance. 

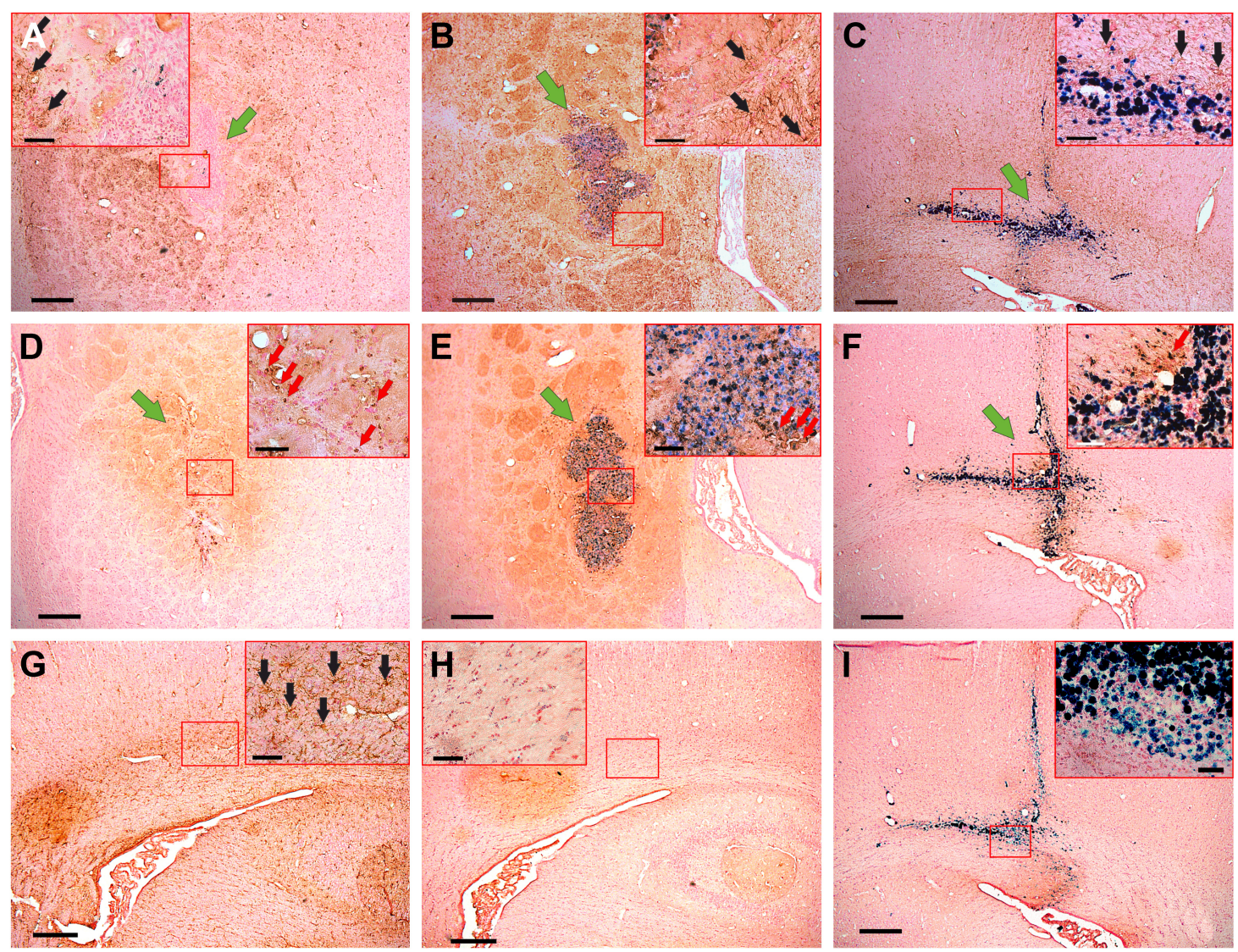

Figure 3 Rat MSCs grafted into a rat brain.

Notes: GFAP positive cells (black arrows) surrounding the unlabeled (A), CZF-NP-labeled (B), and SPION-labeled cells (C) I month after injection. Only a few CD68 positive cells (red arrows) were present around the unlabeled (D), CZF-NP-labeled (E), and SPION-labeled cells (F); scale bar I00 $\mu \mathrm{m}$. Insets show higher magnification; scale bar $20 \mu \mathrm{m}$. Green arrows mark the cell implant. GFAP positive cells (black arrows) in the healthy tissue without graft (G). No CD68 positive cells were found in healthy tissue of animals without graft $(\mathbf{H})$. Staining visualized using an avidin/biotin-based peroxidase system omitting the primary antibody (I). Transplant with nanoparticles is visualized by Prussian blue staining. Sporadic Prussian blue positive staining in the implant of unlabeled cells (A) reflects heme iron from blood.

Abbreviations: CZF-NP, cobalt-zinc-ferrite nanoparticle; SPION, superparamagnetic iron oxide nanoparticle; MSCs, mesenchymal stem cells; GFAP, glial fibrillary acidic protein.

number of healthy cells from the brain tissue surrounding the implant. Along with the results of immunohistochemistry, this might testify for the negligible harmful effects of the labeled implant on the neighboring tissue. On the other hand, the effects of SPIONs in vitro were analyzed in cells labeled for 72 hours, ${ }^{8}$ while in the present study the labeling interval was shortened from 72 to 48 hours. This could lead to a decrease of intracellular concentration of SPIONs in the rMSCs, which in turn might depreciate the toxic potential of the label.

Table I Oxidative damage to DNA, lipids, and proteins in the rat brains with implants of unlabeled (0), SPION-labeled, or CZF-labeled rat mesenchymal stem cells

\begin{tabular}{|c|c|c|c|c|c|c|c|}
\hline \multirow[t]{2}{*}{ Interval } & \multirow[t]{2}{*}{$\begin{array}{l}\text { rMSC } \\
\text { labeling }\end{array}$} & \multicolumn{2}{|c|}{$\begin{array}{l}\text { DNA damage } \\
\text { tail DNA (\%) }\end{array}$} & \multicolumn{2}{|c|}{ 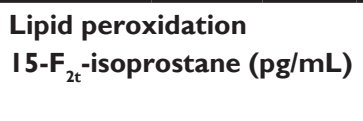 } & \multicolumn{2}{|c|}{$\begin{array}{l}\text { Protein oxidation } \\
\text { carbonyl groups } \\
(\mathrm{nmol} / \mathrm{mg})\end{array}$} \\
\hline & & Mean \pm SD & $P$-value & Mean \pm SD & $P$-value & Mean \pm SD & $P$-value \\
\hline \multirow[t]{3}{*}{24 hours } & 0 & $20.10 \pm 4.10$ & & $51.52 \pm|5.7|$ & & $5.48 \pm 0.22$ & \\
\hline & SPION & $25.94 \pm 3.94$ & 0.2149 & $52.64 \pm 4.83$ & 0.8278 & $4.99 \pm 0.68$ & 0.0539 \\
\hline & $\mathrm{CZF}$ & $29.13 \pm 6.39$ & 0.1699 & $39.73 \pm 6.01$ & 0.3487 & $5.30 \pm 0.33$ & 0.2928 \\
\hline \multirow[t]{3}{*}{4 weeks } & 0 & $22.98 \pm 2.38$ & & $41.33 \pm 7.98$ & & $5.30 \pm 0.14$ & \\
\hline & SPION & $22.35 \pm 1.82$ & 0.7576 & $45.97 \pm 6.23$ & 0.6611 & $5.40 \pm 0.33$ & 0.7058 \\
\hline & $\mathrm{CZF}$ & $18.23 \pm 1.99$ & 0.0557 & $49.58 \pm 7.33$ & 0.4093 & $5.50 \pm 0.22$ & 0.1723 \\
\hline
\end{tabular}

Abbreviations: SD, standard deviation; CZF, cobalt-zinc-ferrite; SPION, superparamagnetic iron oxide nanoparticle; rMSC, rat mesenchymal stem cell. 


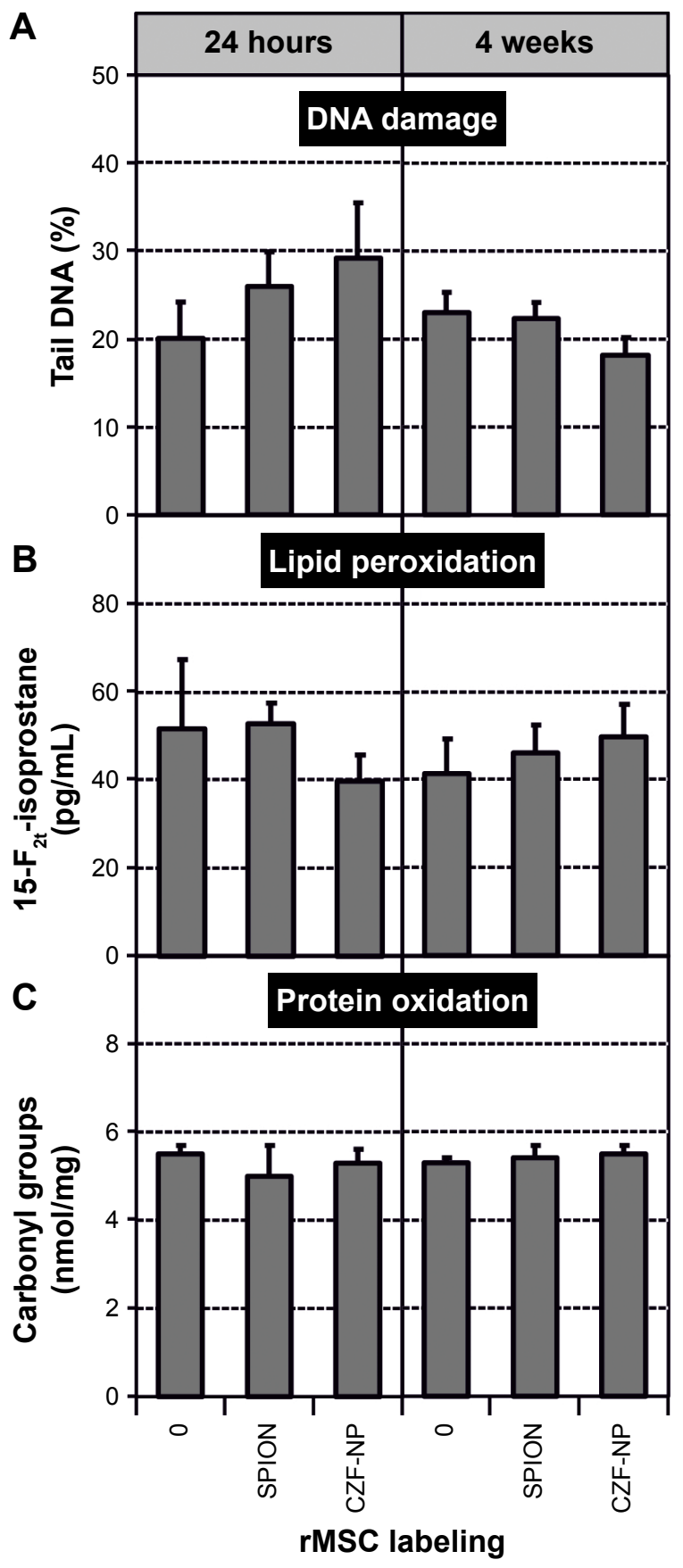

Figure 4 Oxidative damage to DNA (A), lipids (B), and proteins $(\mathbf{C})$ in the brain tissue of rats.

Notes: The tissue samples were collected 24 hours and 4 weeks after implantation of rMSCs into the left hemisphere. DNA damage involved DNA strand breaks and oxidized lesions. Columns represent arithmetic means with marked standard deviations.

Abbreviations: CZF-NP, cobalt-zinc-ferrite nanoparticle; SPION, superparamagnetic iron oxide nanoparticle; rMSCs, rat mesenchymal stem cells.

The undesirable effects of nanoparticles on the surrounding tissue are attributed mainly to the generation of reactive oxygen species by inflammatory cells. ${ }^{20}$ While the rats exposed intravenously to pure SPIONs exhibited, 2 weeks after the treatment, signs of inflammation in the lungs, liver, and kidneys, ${ }^{6}$ no difference in the inflammatory response was observed during the long-term monitoring of animals with SPION-labeled or unlabeled grafts. ${ }^{21}$ It seems that SPIONs applied in the form of an intracellular label at an appropriate concentration do not represent a serious risk for the recipient. This corresponds to some previous promising observations in vivo. For example, SPION-labeled cells were capable of migration in the host to the site of the lesion, differentiated there in an appropriate manner, and improved the functional outcome of the injured animal. ${ }^{22-24}$ Similarly, the secretion profile of iron oxide-labeled hBMSCs did not seem to be impaired, including the production of growth factors and cytokines mediating the recovery effect..$^{25}$

\section{Conclusion}

The first results of our in vivo study suggest that the implantation of rMSCs labeled with SPIONs or CZF-NPs does not induce noticeable oxidative stress in the brain tissue. Hence, not only CZF-NPs but also SPIONs coated with PLL appear to be a prospective label for the tracking of transplanted cells by MR.

\section{Acknowledgments}

This work was supported by the Czech Science Foundation under the project 16-04340S, by LO1309 and LO1508 of the Ministry of Education, Youth and Sports under the National Program of Sustainability I program from the European Regional Development Fund and from the Norwegian Financial Mechanism 2009-2014, and by the Ministry of Education, Youth, and Sports under project contract no MSMT-28477/2014 (project 7F14057).

This paper was presented in part at the NANOCON (Ninth International Conference on Nanomaterials, October 19-21, 2016) as an oral presentation with interim findings. The actual paper, however, has never been published.

\section{Disclosure}

Pavla Jendelova, Karolina Turnovcova and Vit Herynek are co-originators of Czech patent application PV 2015-606 "Nanoparticles for magnetic and fluorescent labeling, their preparation, production and use." The other authors report no conflicts of interest in this work.

\section{References}

1. Li L, Jiang W, Luo K, et al. Superparamagnetic iron oxide nanoparticles as MRI contrast agents for non-invasive stem cell labeling and tracking. Theranostics. 2013;3(8):595-615.

2. Jasmin, Torres AL, Jelicks L, de Carvalho AC, Spray DC, Mendez-Otero R. Labeling stem cells with superparamagnetic iron oxide nanoparticles: analysis of the labeling efficacy by microscopy and magnetic resonance imaging. Methods Mol Biol. 2012;906:239-252. 
3. Valdiglesias V, Fernández-Bertólez N, Kilic G, et al. Are iron oxide nanoparticles safe? Current knowledge and future perspectives. J Trace Elem Med Biol. 2016;38:53-63.

4. Donaldson K, Borm P, Castranova V, Gulumian M. The limits of testing particle-mediated oxidative stress in vitro in predicting diverse pathologies; relevance for testing of nanoparticles. Part Fibre Toxicol. 2009;6:13-21

5. Shetab-Boushehri SV, Abdollahi M. Current concerns on the validity of in vitro models that use transformed neoplastic cells in pharmacology and toxicology. Int J Pharm. 2012;8(6):594-595.

6. Hanini A, Schmitt A, Kacem K, Chau F, Ammar S, Gavard J. Evaluation of iron oxide nanoparticle biocompatibility. Int J Nanomedicine. 2011;6:787-794.

7. Jarockyte G, Daugelaite E, Stasys M, et al. Accumulation and toxicity of superparamagnetic iron oxide nanoparticles in cells and experimental animals. Int J Mol Sci. 2016;17(8):1193-1215.

8. Novotna B, Jendelova P, Kapcalova M, et al. Oxidative damage to biological macromolecules in human bone marrow mesenchymal stromal cells labeled with various types of iron oxide nanoparticles. Toxicol Lett. 2012;210(1):53-63.

9. Novotna B, Turnovcova K, Veverka P, et al. The impact of silica encapsulated cobalt zinc ferrite nanoparticles on DNA, lipids and proteins of rat bone marrow mesenchymal stem cells. Nanotoxicology. 2016; 10(6):662-670.

10. Babic M, Horak D, Trchova M, et al. Poly(L-lysine)-modified iron oxide nanoparticles for stem cell labeling. Bioconjug Chem. 2008;19(3): 740-745.

11. Dominici M, Le Blanc K, Mueller I, et al. Minimal criteria for defining multipotent mesenchymal stromal cells. The International Society for Cellular Therapy position statement. Cytotherapy. 2006;8(4): 315-317.

12. Vanecek V, Zablotskii V, Forostyak S, et al. Highly efficient magnetic targeting of mesenchymal stem cells in spinal cord injury. Int JNanomedicine. 2012;7:3719-3730.

13. Forostyak S, Homola A, Turnovcova K, Svitil P, Jendelova P, Sykova E. Intrathecal delivery of mesenchymal stromal cells protects the structure of altered perineuronal nets in SOD1 rats and amends the course of ALS. Stem Cells. 2014;32(12):3163-3172.
14. Jendelova P, Herynek V, Urdzikova L, et al. Magnetic resonance tracking of transplanted bone marrow and embryonic stem cells labeled by iron oxide nanoparticles in rat brain and spinal cord. J Neurosci Res. 2004; 76(2):232-243.

15. Singh NP, McCoy MT, Tice RR, Schneider EI. A simple technique for quantitation of low levels of DNA damage in individual cells. Exp Cell Res. 1988;175(1):184-191.

16. Tice RR, Agurell E, Anderson D, et al. Single cell gel/comet assay: guidelines for in vitro and in vivo genetic toxicology testing. Environ Mol Mutagen. 2000;35(3):206-221.

17. Collins AR. The comet assay for DNA damage and repair: principles, applications, and limitations. Mol Biotechnol. 2004;26(3):249-261.

18. Novotna B, Topinka J, Solansky I, Chvatalova I, Lnenickova Z, Sram RJ. Impact of air pollution and genotype variability on DNA damage in Prague policemen. Toxicol Lett. 2007;172(1-2):37-47.

19. Hanzalova K, Rossner P Jr, Sram RJ. Oxidative Damage Induced by Carcinogenic Polycyclic Aromatic Hydrocarbons and Organic Extracts From Urban Air Particulate Matter. Mutat Res. 2010;696(2): 114-121.

20. Donaldson K, Poland CA, Schins RP. Possible genotoxic mechanisms of nanoparticles: criteria for improved test strategies. Nanotoxicology. 2010;4(4):414-420.

21. Guzman R, Uchida N, Bliss TM, et al. Long-term monitoring of transplanted human neural stem cells in developmental and pathological contexts with MRI. Proc Natl Acad Sci USA. 2007;104(24): $10211-10216$

22. Zhang ZG, Jiang Q, Zhang R, et al. Magnetic resonance imaging and neurosphere therapy of stroke in rat. Ann Neurol. 2003;53(2):259-263.

23. Urdzikova L, Jendelova P, Glogarova K, Burian M, Hajek M, Sykova E. Transplantation of bone marrow stem cells as well as mobilization by granulocyte-colony stimulating factor promotes recovery after spinal cord injury in rats. J Neurotrauma. 2006;23(9):1379-1391.

24. Amemori T, Romanyuk N, Jendelova P, et al. Human conditionally immortalized neural stem cells improve locomotor function after spinal cord injury in the rat. Stem Cell Res Ther. 2013;4(3):68-82.

25. van Buul GM, Kotek G, Wielopolski PA, et al. Clinically translatable cell tracking and quantification by MRI in cartilage repair using superparamagnetic iron oxides. PLoS One. 2011;6(2):e17001.
International Journal of Nanomedicine

\section{Publish your work in this journal}

The International Journal of Nanomedicine is an international, peerreviewed journal focusing on the application of nanotechnology in diagnostics, therapeutics, and drug delivery systems throughout the biomedical field. This journal is indexed on PubMed Central, MedLine, CAS, SciSearch ${ }^{\circledR}$, Current Contents ${ }^{\circledR} /$ Clinical Medicine,

\section{Dovepress}

Journal Citation Reports/Science Edition, EMBase, Scopus and the Elsevier Bibliographic databases. The manuscript management system is completely online and includes a very quick and fair peer-review system, which is all easy to use. Visit http://www.dovepress.com/ testimonials.php to read real quotes from published authors. 